\title{
Developing mobile learning based on ethnomathematics viewed from adaptive e-learning: Study of two dimensions geometry on Yogyakarta palace's chariot
}

\author{
Nuryadi ${ }^{a, 1, *}$, Luky Kurniawan ${ }^{\text {b,2, Isna Kholifa }}{ }^{\text {a,3 }}$ \\ ${ }^{a}$ Pendidikan Matematika, Universitas Mercu Buana Yogyakarta, Indonesia \\ ${ }^{\mathrm{b}}$ Bimbingan dan Konseling, Universitas Mercu Buana Yogyakarta, Indonesia \\ ${ }^{1}$ nuryadi@mercubuana-yogya.ac.id; ${ }^{2}$ luky@ mercubuana-yogya.ac.id; ${ }^{3}$ isna@ @ercubuana-yogya.ac.id \\ * corresponding author
}

ARTICLE INFO

Article history

Received 2020-04-08

Revised 2020-04-09

Accepted 2020-05-28

Keywords

Mobile learning

Ethno-mathematic

Adaptive e-learning.

\section{ABSTRACT}

This research aims to develop mobile mathematics learning media based on ethnomathematics on the best rectangular view from criteria, validity, practicality, and effectiveness. This research was Research and Development (R\&D) refers to the developing model of ADDIE. The steps of ADDIE developing models were: (1) analysis, problem analysis and media content analyze; (2) design, made storyboards and flowcharts; (3) development, developing initial products including design planning and design implementation; (4) implementation, reality trials both small and large scale; and (5) evaluation, product revision and final product. Ethnomathematics elements used in this research were parts of the Yogyakarta Palace's chariot using the main application named Adobe Flash CS6. The research's results showed that it has completed: (1) the validity aspect, the material experts got a score 68 with an excellent grade, and the media experts got a score of 73 with an excellent grade; (2) the practicality aspect, with assessors from 32 students getting 2006 of a score with an excellent grade; and (3) the effectiveness aspect, with virtual ability test that has $92,7 \%$ of students who completed. So, this mobile learning based on ethnomathematics is appropriated as mathematics learning media through adaptive e-learning on the study of two-dimensions geometry.

This is an open access article under the CC-BY-SA license.

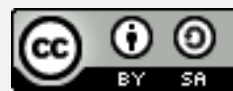

\section{Introduction}

The National Council of Teachers of Mathematics states that there are six principles of school mathematics, namely justice, curriculum, teaching, learning, assessment, and technology. Related to technology, NCTM states that "technology is essential in teaching and learning mathematics, it influences the mathematics that is taught and enhances student's learning." The position of technology in learning mathematics is very essential because it affects the mathematics being taught and improves the quality of student learning [1].

Technology is mostly created to make human life more easy and comfortable. All the conveniences obtained from this smartphone cause addiction or addiction to many people. According to Fatimah the presence of smartphones as mobile learning is intended to complement learning and provide opportunities for students to learn material that is not mastered anywhere and anytime [2].

The use of mobile learning has the potential to help improve student academic performance in the form of learning outcomes in the cognitive domain, student motivation, and learning is not limited by time and place. According to Putriani [3] the teacher's effort to support the implementation of the 2013 
curriculum is the use of varied methods and media in learning by following the latest knowledge developments. So the purpose of learning mathematics in schools is to train students to act based on of logical, rational, critical, careful, honest, effective, and efficient thinking and can use mathematics in daily life [4].

According to Pinxten [5] states that mathematics is essentially a technology that grows on environmental cultural skills or activities, so that one's mathematics is influenced by their cultural background, because what they do is based on what they see and feel. According to Ayuningtyas \& Setiana [6], education and culture are something that cannot be avoided in daily life and is a basic need for every individual in instilling the character of virtuous students.

One way of learning that can bridge between culture and education, especially mathematics, is ethnomathematics. During the learning process based on Ethnomathematics according to Ubiratan D'ambroso [7] stated that something very broad refers to the socio-cultural context, including language, jargon, codes of behavior, myths, and symbols. This tendency is a technique to explain, know, understand, and carry out coding, measuring, classifying, and summarizing activities. In culture responsive learning, mathematics teachers are expected to be able to realize mathematics as a science that is inherent in culture (cultural bounded) in learning. For this reason, teachers need to understand the social and cultural background of their students. Teachers need to have knowledge of the potential of local culture related to mathematics, understand the mathematical knowledge students get from their daily activities and have the skills to design mathematics learning using culture [8].

Study of cultural elements into learning following the contextual principle, where learning utilizes things that are in the surrounding environment or the surrounding culture. One of the proper studies objects to be used as a reference in ethnomatematics learning is the Yogyakarta Katon Kencana Train, see Fig.1.

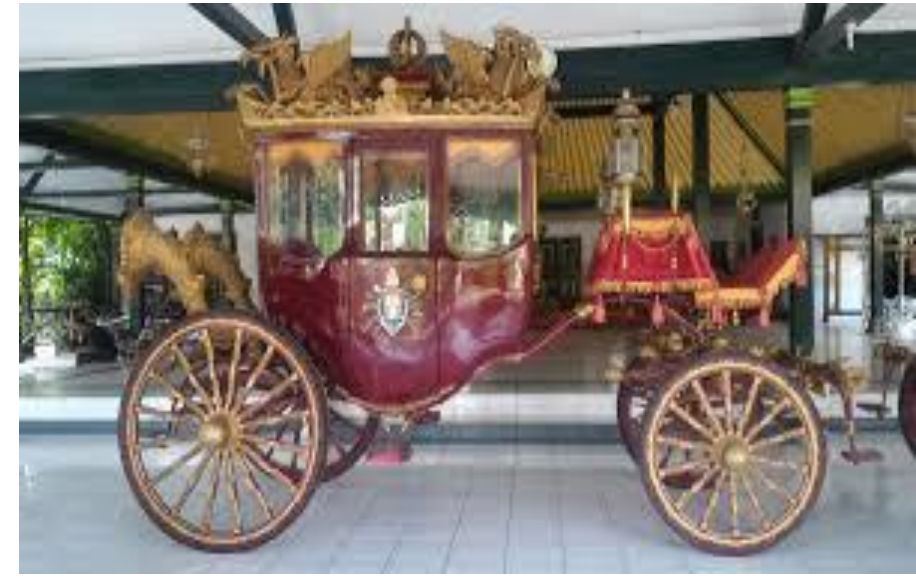

Fig. 1. Yogyakarta kencana train

To support the ethnomathematics study, an Android-based mobile learning device is needed in terms of adaptive e-learning. According to Sugiman, adaptive e-learning is a form of teaching and learning that uses electronic circuits to convey content, interaction or in terms of the use of the website or software-based media [9]. The use of e-learning in mathematics learning has influenced the transformation of conventional education into digital form, both in content and system. The novelty of the study is developing mobile learning based on ethnomathematics viewed from adaptive elearning (study of two-dimensions geometry on Yogyakarta palace's chariot). So, this research aims to develop mobile mathematics learning media based on ethnomathematics on best rectangular viewed from criteria, validity, practicality, and effectiveness. 


\section{Method}

\subsection{Research type and design}

This type of research is R\&D (Research and Development). This is following the research objectives, namely to develop ethnomathematics based mobile learning. According to Borg \& Gall [10] that research and development (Research \& Development) is a research method used to develop or validate products used in education and learning.

This application product follows the design of ADDIE media development (Analysis, Design, Development, Implementation, Evaluation). The steps for development by ADDIE include the following: (1) Analysis: problem analysis and analysis of media content; (2) Design: making storyboards and flowcharts; (3) Development: developing initial products including design design and design implementation; (4) Implementation: Field trials both small and large scale; and (5) Evaluation: product revision and final product.

\subsection{Population and Research Samples}

The population in this study were VII grade students of SMP Negeri 2 Godean which involved a sample of 128 students. The sample in this study class VIIC as many as 32 students of media users and assessors of ethnomathematics based mobile learning media products.

\subsection{Research Development Procedure}

The procedure of developing this research refers to the ADDIE design, namely: (1) Analysis: at this stage the activities under taken are analyzing the needs and characteristics of students, analyzing the curriculum to determine the competency of learning outcomes, selecting and determining the subject matter to be developed, and developing evaluation tools; (2) Design: at this stage, the development of making storyboards and flowcharts, (3) Production: at this stage packaging material to the application form in Android with the help of Adobe Flash CS 6 software, according to the storyboard that has been made; (4) Implementation: in this stage, a trial will be conducted. before the trial is carried out, a review or validation is conducted by material experts and media experts on the developed multimedia products, (5) Then a trial is carried out with the following steps: (a) One-onone trial, (b) Group trial (c) large group trials / field trials. Revisions are made after each trial is based on suggestions and criticisms from the test subjects; and (6) Evaluation: in this stage evaluation of learning media that has been made is based on the results of the learning media evaluation questionnaire. Based on the results of this evaluation, it can be known the expected characteristics of ethnomatematics based mobile learning media.

According to Nieveen [11] said the product quality, design, development, and evaluation of the program must meet valid, practical and effective criteria. To illustrate the validity criteria of a learning product that is if the learning device can describe the curriculum that is expected or intended, which is a combination of ideal and formal.

Conduct preliminary tests on product design by mathematics learning experts, mathematics subject teachers, and media experts. Material experts and learning mathematics aims to assess the validity of multimedia learning mathematics from the material aspects. In addition, because the validity of the product is not only reviewed from the material and learning aspects but also from the media aspect. Therefore to assess the validity of the product is also reviewed from the aspect of the media that is assessed by media experts.

To test the practicality can be seen from the opinions of users, especially teachers and students who consider the products produced are easy to use and also describe the actual learning process. This means that there is consistency between the intended and perceived curriculum and the intended and operational curriculum. If both are consistent then the product is said to be practical. Based on the opinion above, then for the level of practicality in ethnomatematics-based mobile learning mathematics media in terms of teacher assessment and student assessment. For this reason, the practical aspect is associated with the assessment of users (teachers and students) stating the products developed are easy to use. As for the level of effectiveness refers to the ideal criteria for completeness for each indicator is $75 \%$. 


\subsection{Data analysis}

Data analysis was performed to determine the quality of learning tools in terms of validity, practicality, and effectiveness. The data analysis process is carried out when all data has been collected. Data analysis was performed to obtain quality Augmented reality-based learning media products that met the criteria of validity, practicality, and practicality.

First, practicality analysis, the instrument used in the validity analysis is a learning media assessment sheet for material experts, media experts, and junior high school mathematics teachers. According to Widyoko [12],[13] the steps of the analysis were carried out, namely (1) Tabulation of data, (2) Calculation of Average Aspect Scores, (3) Comparison of Average Score of Each Aspect, (4) Calculation of Average Average Score Total Media Rating, (5) Comparison of Average Total Score, (6) Validity Analysis of Learning Media

Data tabulation, is carried out by providing an assessment of aspects of the assessment based on the rating scale measurement scale on the value provided by the validator. The validators in question are material experts, media experts, and teachers. Guidelines for evaluating the media validity assessment sheet in Table 1.

Table 1. Guidelines for Assssment of Learning Media

\begin{tabular}{cc}
\hline Alternative Choices & Value \\
\hline Very Good & 5 \\
Good & 4 \\
Enough & 3 \\
Less & 2 \\
Very Less & 1 \\
\hline
\end{tabular}

Calculation of the average score of aspects can be calculated using the formula $\bar{X}=\frac{\sum x}{n}$ with the provisions of $\bar{X}$ (average score of each aspect), $\sum x$ (total score of each aspect), $n$ (number of statements). After getting an average score of each aspect in the previous stage, then the score is expressed in a qualitative value by comparing it with certain assessment criteria. The criteria used are presented in the following Table 2.

Table 2. Learning Media Quality Assessment Criteria

\begin{tabular}{cc}
\hline Score Interval & Criteria \\
\hline $\bar{X}_{i}+1.8 s b_{i}<\bar{X}$ & Very Godd \\
$\bar{X}_{i}+0.6 s b_{i}<\bar{X} \leq \bar{X}_{i}+1.8 s b_{i}$ & Good \\
$\bar{X}_{i}-0.6 s b_{i}<\bar{X} \leq \bar{X}_{i}+0.6 s b_{i}$ & Enough \\
$\bar{X}_{i}-1.8 s b_{i}<\bar{X} \leq \bar{X}_{i}-0.6 s b_{i}$ & Less \\
$\bar{X} \leq \bar{X}_{i}-1.8 s b_{i}$ & Very Less \\
\hline
\end{tabular}

With the provisions of $\bar{X}_{i}$ ideal average $\left(\frac{1}{2}\right.$ ideal maximum score + ideal minimum score $), s b_{i}$ ideal standard deviation $\left(\frac{1}{6}\right.$ ideal maximum score-ideal minimum score), $\bar{X}$ (average score), deal maximum score (highest score), ideal minimum score (lowest score).

Material expert assessment is carried out by one assessor with many items of assessment for material experts, namely 17 items. Thus the ideal minimum score $=17$, the maximum maximum score $=85, \bar{x}_{\mathrm{i}}=51$ and $\mathrm{SBi}=11.33$ can be obtained. Whereas the assessment of media experts is done by one assessor with many items of evaluation for media experts, namely 16 items. Thus the ideal minimum score $=16$, the maximum maximum score $=80, \bar{x}_{\mathrm{i}}=48$ and $\mathrm{SBi}=10.66$ can be obtained. Next, determine the interval criteria for the results of the media expert and material expert questionnaire using the guidelines according to Table 3. and Table 4. as follows. 
Table 3. Conversion of Media Expert Judgment

\begin{tabular}{cc}
\hline Average Interval Score & Criteria \\
\hline$X>71,39$ & Very Good \\
$57,78<\bar{X} \leq 71,39$ & Good \\
$44,22<\bar{X} \leq 57,78$ & Enough \\
30,66 & $<\bar{X} \leq 44,22$ \\
$\bar{X}$ & Less \\
\hline
\end{tabular}

Table 4. Conversion of Expert Material Judgments

\begin{tabular}{|c|c|}
\hline Average Interval Score & Criteria \\
\hline$X>67,18$ & Very Good \\
\hline $54,39<\bar{X} \leq 67,18$ & Good \\
\hline $41,60<\bar{X} \leq 54,39$ & Enough \\
\hline $28,81<\bar{X} \leq 41,60$ & Less \\
\hline $\bar{X} \leq 28,81$ & Very Less \\
\hline
\end{tabular}

Ethnomatematics-based mobile learning media in this study are said to be valid if the results of the validation of learning media according to material experts, media experts, and teachers are categorized as minimal either according to table 3 and table 4 henceforth it is worth testing.

The second practicality analysis, based on the results of the analysis of student response questionnaire with steps namely (1) tabulating student response questionnaire data, (2) calculation of average aspect scores, (3) conversion of average scores, (4) analysis of media practicality learning. Tabulate data from the results of student response questionnaires using the reference assessment guide in Table 5.

Table 5. Guidelines for Evaluating Student Response Questionnaire

\begin{tabular}{ccc}
\hline & Alternative Choices & \multirow{2}{*}{ Value } \\
\hline Positive Questions & Negatove Questions & 4 \\
Strongly Agree & Strongly Disagree & 3 \\
Agree & Disagree & 2 \\
Disagree & Agree & 1 \\
Strongly Disagree & Strongly Agree &
\end{tabular}

The average score of an aspect can be calculated using the formula $\bar{X}=\frac{\sum x}{n}$ with the condition $\bar{X}$ (average score of each aspect), $\sum x$ (the total score of each aspect), $n$ ( number of statement items).

To analyze the practicality of instructional media, it is done by converting the average scores obtained into quality based on the scoring criteria of the scale 4. Assessment of all grade VII students C. The results of the assessment of the material expert and the media expert are then seen from the conversion conversion from the Azwar assessment interval formula. Student assessments are carried out by 9 assessors in small groups and 32 assessors for large groups with many assessment items for students which are 15 items. Thus the first trial obtained an ideal minimum score $=135$, an ideal maximum score $=675, \bar{x}_{\mathrm{i}}=405$ and $\mathrm{SBi}=90$. While for the final trial the ideal minimum score $=$ 480 , the maximum maximum score $=2400, \bar{x}_{\mathrm{i}}=1440$ and $\mathrm{SBi}=320$, so we get the conversion guidelines in the following Table 6 and Table 7. 
Table 6. Conversion

\begin{tabular}{cc}
\hline Small Group & Criteria \\
\hline$X>567$ & Very Good \\
$450<X \leq 567$ & Good \\
$360<X \leq 450$ & Enough \\
$243<X \leq 360$ & Less \\
$X \leq 243$ & Very Less \\
\hline
\end{tabular}

Table 7. Conversion of Student Assessments

\begin{tabular}{cc}
\hline Small Group & Criteria \\
\hline$X>2016$ & Very Good \\
$1632<X \leq 2016$ & Good \\
$1248<X \leq 1632$ & Enough \\
$864<X \leq 1248$ & Less \\
$X \leq 864$ & Very Less \\
\hline
\end{tabular}

Ethnomatematics-based mobile learning media developed in this study are considered to be practical if the average scores obtained from student questionnaires are at least good. Third, effectiveness analysis. The data used to measure the effectiveness of ethnomatematics-based mobile learning media is the e-learning test results of student learning after using learning tools developed by researchers. Analysis of student learning outcomes tests is done by quantitative analysis by determining the average test scores classically. The average test scores obtained from the sum of the scores obtained by students, then divided by the number of students who took the test, the average aspect score can be calculated using the formula $\bar{X}=\frac{\sum x}{\sum N}$ with $\bar{X}$ conditions (average grade), $\sum x$ (total number of students), $\sum N$ (number of students taking the test).

Individual learning outcomes are said to be complete if students meet the Minimum Mastery Criteria (KKM) which is 75\% according to what has been determined by SMP Negeri 2 Godean. Whereas learning media is said to be effective if the average value of classical learning outcomes reaches a minimum value of 75 .

\section{Results and Discussion}

Ethnomatematics-based mobile learning media can be said to be validated based on data from media expert instruments and material on learning media. The results of the assessment of learning media by media experts and material experts relating to the quality of the media in the aspects of validity assessment are summarized in Table 8.

Table 8. Data Validity Score Ethnomatematics Base Mobile Learning Media

\begin{tabular}{cccc}
\hline No. & Aspect & Score & Category \\
\hline 1. & Math material and learning & 68 & Very Good \\
2. & Ethnomatematics based mobile learning media & 73 & Very good \\
\hline
\end{tabular}

Based Table 8, the results of data analysis from experts obtained a score from material experts, which is 68 , which is above the value of 67.18 with very good information and from media experts, which is 73 , which is above 71.39 , with very good information. The results obtained from the assessment of material and media experts indicate that the virtual-based interactive learning media in the category is very good, so that the virtual-based interactive learning media that has been developed can be declared valid for use. 


\subsection{Practical Analysis of Mathematics Learning Media}

To find out the practicality of the product developed the data used is data about teacher and student assessment of ethnomatematics-based mobile learning media. Based on the questionnaire sheets given to 32 students, data on student assessment of ethnomatematics based mobile learning media as presented in Table 9.

Table 9. Practical Score Data on Mathematics Learning Media

\begin{tabular}{cccc}
\hline No & Assessor & Score & Category \\
\hline 1 & Student & 2066 & Very Good \\
\hline
\end{tabular}

Base on Table 9. above the scores obtained for practicality of products based on student assessment are 2066 which are in the range of scores above 2016 so that the practicality of products based on student assessment is included in the excellent category.

The assessment of the practicality of the product from students consistently stated good. Therefore, from the data obtained from student assessments it can be concluded that the product developed in the form of ethnomatematics-based mobile learning media can be declared practical so that it is feasible to use.

\subsection{Analysis of the effectiveness of ethnomatematics-based mobile learning}

To find out the effectiveness of the TGT-based virtual mathematics learning media developed the problem solving ability test instrument was used. Based on data from the eighth grade student test results, a total of 64 students obtained the results of the analysis as in Table 10.

Table 10. Analysis of Adaptive e-learning Test Data

\begin{tabular}{ccc}
\hline Type of test & Number of students who completed & The percentage of students who completed \\
\hline Virtual ability test & 32 & $92,7 \%$
\end{tabular}

Based on Table 10 above the percentage of students completeness is $92.7 \%$. This shows that the individual completeness of students has reached the minimum completeness limit of $75 \%$. So it can be concluded that the product developed is effective in terms of adaptive e-learning.

\subsection{Final Product Review}

After a series of development stages, the final product in the form of ethnomatematics based mobile learning media has been declared valid, practical, and effective through analysis of the data obtained. The product developed has been through the validation and assessment process by making revisions 3 times. Ethnomatematics-based mobile learning media for learning is also intended to improve the ability of adaptive e-learning in learning mathematics.

The quality of the product developed was also stated to be very good based on the material expert assessments and mathematics learning, media experts and students so that it was appropriate to be used for a larger scale. This product is designed as a learning medium that teachers can use to deliver class material.

Based on the analysis through the results of observations and interviews, the names and parts of the Yogyakarta kencana kencana train are in the form of the Garuda Yeksa kencana train, the Roto Proloyo train, and the customs landower, see Table 11 and Table 12. The parts of the Yogyakarta kencana chariot train have mathematical aspects of triangles and rectangles so that they can be linked to mathematics materials at school. The following ethnomatematics on the Yogyakarta royal kencana train. 
Table 11. Ethnomatematics on Yogyakarta Palace Train

\begin{tabular}{|c|c|}
\hline Parts that contain mathematical elements & $\begin{array}{c}\text { Mathematical aspects of school that } \\
\text { can be learned }\end{array}$ \\
\hline $\begin{array}{c}\text { Function } \\
\text { Identification Kyai Garuda Yeksa Kencana Tain } \\
\text { Sri Sultan Hamengkubuwono's Yogyakarta coronary chariot } \\
\text { train }\end{array}$ & $\begin{array}{c}\text { Garuda Yeksa Kencana train consists of } \\
\text { several forms of flat shape including: } \\
\text { Square } \\
\text { Rectangle } \\
\text { Triangle } \\
\text { Trapezoid } \\
\text { Circle }\end{array}$ \\
\hline 40 & $\begin{array}{l}\text { Praloyo Roto train consists of several } \\
\text { forms of flat shape including: } \\
\text { Square } \\
\text { Rectangle } \\
\text { Trapezoid } \\
\text { Circle }\end{array}$ \\
\hline $\begin{array}{c}\text { Identification: } \\
\text { Roto Proloyo Kencana Train } \\
\text { Function: } \\
\text { Sri Sultan Hamengkubuwono's remains train }\end{array}$ & \\
\hline
\end{tabular}

Table 12. Ethnomatematics on Yogyakarta Palace Train (Advanced)

Parts that contain mathematical elements
$\begin{gathered}\text { Mathematical aspects of school that } \\ \text { can be learned }\end{gathered}$
$\begin{gathered}\text { Landower train consists of several forms } \\ \text { of flat structure including: } \\ \text { Square } \\ \text { Rectangle } \\ \text { Cut the rice cake } \\ \text { Circle }\end{gathered}$
Ngabean Landower Trains
Function:

The mathematical context that has been identified on the Yogyakarta kencana chariot train indicates that the activities, and creations of previous people were already familiar with and related to mathematics. From the results of the identification of ethnomatematics in the form of Yogyakarta kencana train chariot, this study produced a product in the form of mobile learning media Mathematics learning on quadrilateral and triangular material with ethnomatematics approach for seventh grade junior high school students. This learning media consists of various forms of animation as game icons, images with ethnomatematics as learning materials and quizzes, and music as background sound on this media. 


\section{Conclusion}

The product developed was in the form of a medium for learning mathematics on mobile learning based on ethnomatemics basic subject matter of basic geometry. The development of ethnomatematics-based mobile learning media is supported by Adobe Flash CS6 software which was adapted from the ADDIE model, namely: (1) analysis, problem analysis and analysis of media content; (2) design, making storyboards and flowcharts; (3) development, developing initial products including design design and design implementation; (4) implementation, field trials both small and large scale; and (5) evaluation, product revision and final product. Judging from the quality criteria of the final product, ethnomatematics-based mobile learning media for seventh grade junior high school students is declared valid. The results of the assessment of the material experts obtained a total score of 68 and included in the category of "very good", viewed from several criteria including material and questions, supporting learning materials, material updates, language, presentation techniques, presentation of learning, and presentation comprehension. The results of the assessment by media experts obtained a total score of 73 and included in the category of "very good", seen from several criteria including performance, audio and visual display, software engineering. Judging from the practicality criterion, ethnomatemics-based mobile learning media for mathematics learning media for seventh grade junior high school students is practical on flat field Geometry material. This is determined from the results of the assessment of 32 students. The results of the assessment of 30 students obtained a total score of 2066 and included in the category of "very good", seen from several criteria including, aspects of learning interest, aspects of ease of understanding, and aspects of media presentation. Judging from the effectiveness criteria, the mathematics learning media of mobile learning based on ethnomatematics using Adobe Flash CS6 on flat geometry material for seventh grade junior high school students is effective in terms of adaptive e-learning. This is indicated from the percentage of mastery learning by $92.7 \%$ of 32 students in one class meet the KKM value.

\section{References}

[1] NTCM. Principles and standars for school mathematics. United States: National Council of Teacher of Mathematics, Inc. 2000, available at: Google Scholar.

[2] Fatimah, S., \& Mufti, Y. Pengembangan media pembelajaran IPA-fisika smartphone berbasis android sebagai penguat karakter sains siswa. Jurnal Kaunia, 10(1), 59-64. 2014, available at: Google Scholar.

[3] Putriani D., Waryanto H.N., \& Hernawati K. Pengembangan Media Pembelajaran Berbasis Android Dengan Program Construct 2 Pada Materi Bangun Ruang Sisi Datar Untuk Siswa Smp Kelas 8. Jurnal Pendidikan Matematika, Vol.6, No.3, hal 1-10. 2017, available at: Google Scholar.

[4] Suherman E., Turmudi, Suryadi D, Herman T, Suhendra, Prabawanto S., Nurjanah, \& Rohyati A. Strategi Pembelajaran Matematika Kontemporer. Bandung: JICA. 2003, available at: Google Scholar.

[5] Tandililing E. Pengembangan Pembelajaran Matematika Sekolah denganPendekatan Etnomatematika Berbasis Budaya Lokal Sebagai Upaya Untuk Meningkatkan Kualitas Pembelajaran di Sekolah. Prosiding. Seminar Nasional Matematika dan Pendidikan Matematika. 2013, available at: Google Scholar.

[6] Ayuningtyas, A.D., \& Setiana, D.S. Bahan ajar matematika berbasis etnomatematika Kraton Yogyakarta. Prosiding Sendika, 4(1). 2018, doi: 10.24127/ajpm.v8i1.1630.

[7] D'Ambrosio U. General remarks on ethnomathematics. ZDM. 2001 Jun 1;33(3):67-9, doi: 10.1007/BF02655696.

[8] Danoebroto, S.W. Studi Kualitatif Tentang Guru Matematika di SMP Sekitar Candi Borobudur Dalam Melaksanakan Pembelajaran yang responsif Budaya. Journal of Mathematics And Education, 3. 2016, available at: Google Scholar.

[9] Sugiman, R.R., \& Retnowati, E. Pengembangan Alat Peraga Matematika Virtual Berbasis Cognitive Load Theory. 2013, available at: Google Scholar. 
[10] Sugiyono. Metode Penelitian Kuantitatif Kualitatif dan R\&D. Bandung: Alfabeta. 2008, available at: Google Scholar.

[11] Nuryadi, N. Pengembangan Media Matemc atika Mobile Learning Berbasis Android Ditinjau Dari Kemampuan Pemecahan Masalah. Jurnal Pendidikan Surya Edukasi (JPSE), 5(1). 2019, doi: 10.37729/jpse.v5i1.5662.

[12] Widoyoko E.P.S. Evaluasi Program Pembelajaran. Yogyakarta: Pustaka Belajar. 2009, available at: Google Scholar.

[13] Orey, D \& Rosa, M. Ethnomathematics: Cultural Assertions and Challanges Toward Pedagogocal Action. Jurnal of mathematics and cultural vol VI (1) ISSN-1558-5336. 2006, available at: Google Scholar. 